\title{
LOS REINOS DE LO SUBTERRÁNEO
}

Ayer aterrizamos y al alba descendimos.

Fumamos

antes de entrar al cenote:

un pozo que conecta con más pozos

los sueños del planeta.

Las hiedras dispersan sus manos por el suelo,

se multiplican

como las venas de mis ojos.

El humo que marchita los pulmones,

los bronquios que son árboles del cuerpo,

nos deja la sed de todas las plantas

en una bocanada.

Después de los cometas, las simas se crearon

$\mathrm{y}$ desde entonces

el agua es lo que alumbra las paredes,

el techo de la gruta es también suelo.

A mediodía la noche en la caverna.

Mientras mis amigos se esconden

detrás de unas columnas,

el espacio que hay entre

estalactitas y estalagmitas,

muy cerca de tocarse,

nos sugiere esperar y ser pacientes

mientras llega un futuro sin retiro

ni historial crediticio.

Encima de nosotros,

raíces como nervios de la tierra

y lianas como raíces en el aire.

Debajo,

la arena florece

más dentro de lo oscuro. 
Con mis goggles baratos

alcanzamos a ver todo el abismo:

valles, grutas, corales laberintos,

peces que rozan las piernas de Laura

y el claro que resalta los ojos de Sofía.

¿En el fondo de todo habrá fogatas?,

¿el cenote es el cielo del abismo

y un eclipse es el fondo del cenote?

Nunca tan alto caí:

somos los turistas en el agua

como los turistas que somos en el tiempo.

Llueve, pero solo arriba.

\section{LO QUE SEA MENOS "BONSÁI"}

\section{Sangre}

Lúgubre y líquida

flor de Jamaica

que dibuja la vida.

\section{Los cerros}

Barcos de vela verde

navegan frente al sol:

se pierden.

\section{Recuerdo de Facebook}

El amor reconoce

la exacta duración de una burbuja.

\section{Gran Turismo}

Un Xbox empolvado.

Se oye una moto GP

en la autopista. 